\begin{tabular}{lccc} 
& GOSPODARKA & SUROWCAMI & MINERALNYMI \\
\hline Tom 28 & 2012 & Zeszyt 3 \\
& DOI & $10.2478 / \mathrm{v} 10269-012-0021-3$ &
\end{tabular}

\title{
Charakterystyka mineralogiczno-chemiczna i teksturalna odpadów poflotacyjnych z przemysłu Zn-Pb pod kątem dalszych rozważań wykorzystania ich jako sorbentów
}

\section{Wprowadzenie}

Odpady poflotacyjne powstają jako produkt uboczny w górnictwie węgla kamiennego oraz w uzyskiwaniu surowców metalicznych, takich jak Cu czy Zn i Pb. Każdy z nich różni się właściwościami fizykochemicznymi, jak również składem mineralnym. Niemniej jednak wiele prac skupia się nad analizą ich wpływu na środowisko oraz metodami praktycznego ich wykorzystania. Badania dotyczą zarówno odpadów poflotacyjnych z górnictwa węglowego (np. Alwaeli, Czech 2009), jak też z górnictwa kruszcowego (np. Girczys, Sobik-Szołtysek 2002; Duda, Witczak 2003).

W przypadku wydobycia rud cynkowo-ołowiowych odpady poflotacyjne są nieodłącznym elementem uzyskiwania koncentratów $\mathrm{Zn}$ i $\mathrm{Pb}$. Podczas przeróbki rud $\mathrm{Zn}-\mathrm{Pb}$ w rejonie Bukowna na poziomie 2,6-2,7 $\mathrm{mln} \mathrm{Mg}$, rocznie powstaje 1,5-1,6 $\mathrm{mln} \mathrm{Mg}$ odpadów poflotacyjnych, co stanowi 57\% wszystkich powstających w tym procesie odpadów (Girczys, Sobik-Szołtysek 2002). Obecnie głównym kierunkiem postępowania z odpadami poflotacyjnymi z działalności ZGH „Bolesław” jest ich składowanie w ilości około 570 tys. Mg rocznie w stawach osadowych o całkowitej powierzchni 110 ha. Dotychczasowe składowanie, które trwa od 1979 roku, spowodowało nagromadzenie tych odpadów w ilości około $42 \mathrm{mln}$ Mg (Pajor 2005).

* Dr inż., Instytut Gospodarki Surowcami Mineralnymi i Energią PAN, Kraków; e-mail: wdowin@min-pan.krakow.pl

** Dr inż., AGH Akademia Górniczo-Hutnicza, Wydział Geologii, Geofizyki i Ochrony Środowiska, Kraków; e-mail: agnieszka.gruszecka@agh.edu.pl 
Odpady poflotacyjne są jedynie częściowo zagospodarowywane. Wykorzystanie odpadów w obrębie samego składowiska pozwala na zagospodarowanie około $60 \%$ odpadów powstających z bieżącej produkcji. Aktualne wykorzystanie niewielkiej ilości tych odpadów polega również na zastosowaniu ich jako składnika podsadzki hydraulicznej oraz jako materiału rekultywacyjnego na terenach pogórniczych do wypełniania zapadlisk i odkrywek (Janiec, Nowak 1973; Szuwarzyński, Kryza 1993; Sztaba i in. 1996; Girczys, Sobik-Szołtysek 1997; Guśpiel i in.1997; Śmieszek, Sobierajski 1998; Jarosiński i in. 2005; Kulczycka i in. 2005; Pajor 2005; Włodarczyk i in. 2005; Butra i in. 2007). Inne próby przemysłowego zagospodarowania nie przełożyły się na praktyczne wykorzystanie tych odpadów. Pogląd o surowcowym znaczeniu odpadów poflotacyjnych zrodził się już w latach osiemdziesiątych dwudziestego wieku, jednak jak dotąd nigdy nie nastapiło prawne uznanie odpadów poflotacyjnych za surowiec wtórny oraz nie sporządzono możliwych do realizacji planów ich zagospodarowania (Girczys, Sobik-Szołtysek 2002).

Od 2006 roku odpady poflotacyjne są wykorzystywane właściwie tylko do budowy obwałowań samego składowiska oraz jako składnik podsadzki hydraulicznej w mieszaninie z piaskiem kwarcowym - w Kopalni „Olkusz-Pomorzany” (Pajor 2005). Brak perspektyw całkowitego zagospodarowania powstających odpadów zmusza do poszukiwania nowych kierunków ich gospodarczego wykorzystania (Alwaeli, Czech 2009).

Celem publikacji jest wstępna charakterystyka mineralogiczna, chemiczna i teksturalna odpadów poflotacyjnych, w aspekcie dalszych analiz pod kątem rozważenia możliwości wykorzystania ich jako sorbentów gazów kwaśnych $\left(\mathrm{SO}_{2}\right.$ i $\left.\mathrm{CO}_{2}\right)$.

\section{Material badawczy}

Materiał badawczy stanowiła próbka odpadu poflotacyjnego pobrana w 2009 roku z bieżącego wytwarzania odpadów transportowana do stawu osadowego $\mathrm{nr}$ 1, leżącego

TABELA 1

Udział frakcji ziarnowych w odpadzie poflotacyjnym (Katalog... 2002)

Content of granulometric fractions in flotation wastes (Katalog... 2002)

\begin{tabular}{|c|c|}
\hline Frakcja [mm] & Zawartość [\%] \\
\hline \hline$<0,025$ & 34,3 \\
\hline $0,025-0,040$ & 11,2 \\
\hline $0,040-0,063$ & 10,1 \\
\hline $0,063-0,1$ & 13,9 \\
\hline $0,1-0,2$ & 18,7 \\
\hline$>0,2$ & 11,8 \\
\hline
\end{tabular}


w południowej części Stawu Zachodniego (rys. 1), który jest własnością ZGH „Bolesław” w Bukownie. Odpady poflotacyjne stanowią drobnoziarnisty materiał (Górecka i in. 1994). W tabeli 1 przedstawiono uśredniony procentowy udział poszczególnych frakcji ziarnowych w odpadzie (Katalog... 2002).

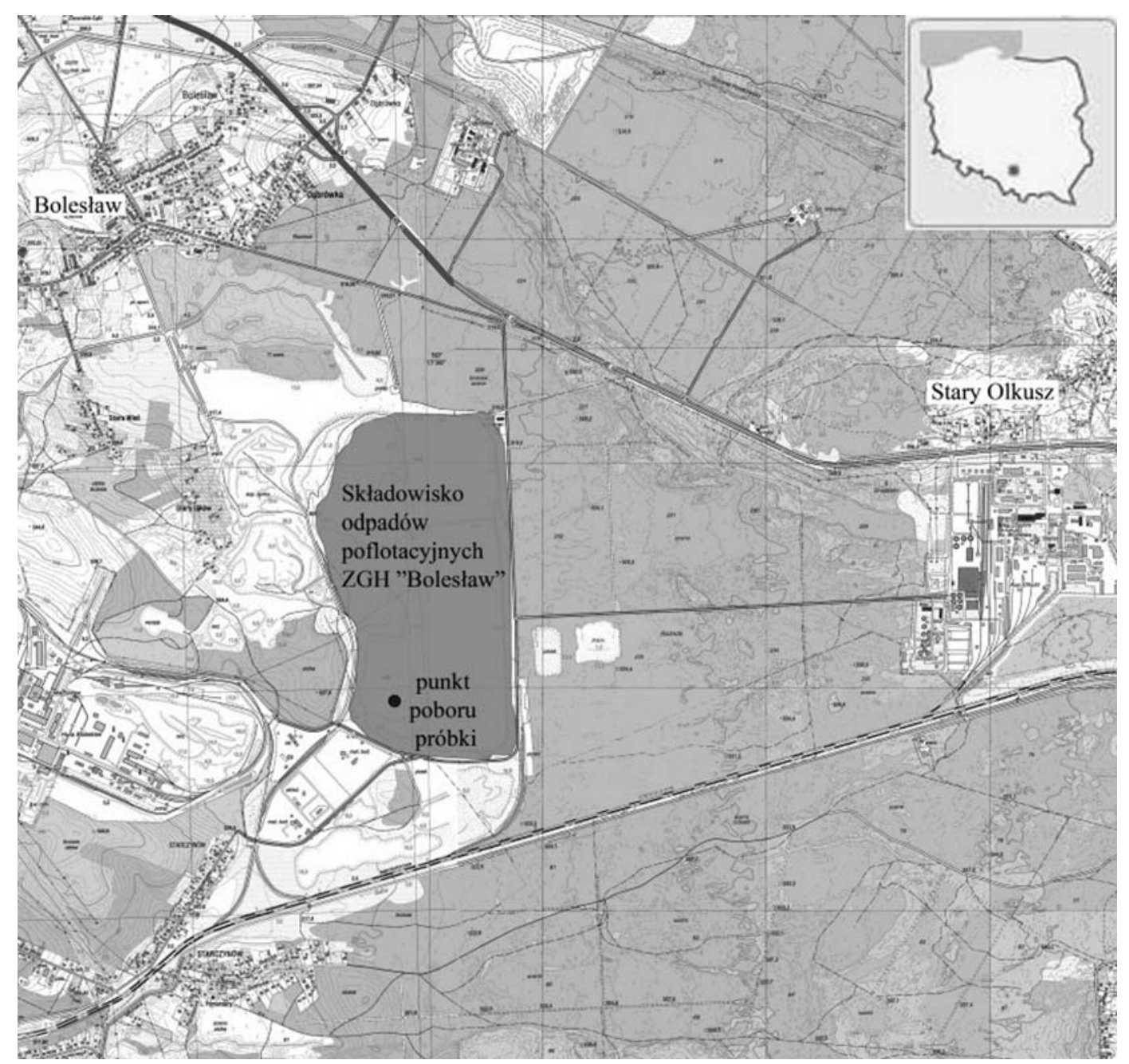

Rys. 1. Lokalizacja stawów osadowych ZGH „Bolesław” w Bukownie (na podstawie mapy topograficznej w układzie „1992” w skali 1:10 000, arkusze: M-34-64-A-a-1, M-34-64-A-a-2, M-34-64-A-a-3, M-34-64-A-a-4)

Fig. 1. Localization of the flotation waste ponds of ZGH "Bolesław" in Bukowno (based on a topographic map in the "1992" reference system, in scale 1:10,000, sheets: M-34-64-A-a-1, M-34-64-A-a-2, M-34-64-A-a-3, M-34-64-A-a-4) 


\section{Metodyka}

Próbka odpadów poflotacyjnych poddana została podstawowym badaniom mineralogicznym, chemicznym i teksturalnym, przy wykorzystaniu szeregu metod badawczych.

Skład mineralny badanej próbki określono za pomocą dyfrakcji rentgenowskiej (XRD) metodą proszkowa, za pomocą dyfraktometru rentgenowskiego DRON-3.0, stosując następujące parametry: promieniowanie $\mathrm{Cu}_{\mathrm{K} \alpha}$, filtr $\mathrm{Ni}$, napięcie lampy $35 \mathrm{kV}$, prąd lampy $30 \mathrm{~mA}$, rejestracja krokowa: krok $0,05^{\circ} 2 \Theta$, czas zliczania 1 sek/krok. W celu wyeliminowania wpływu czynników aparaturowych na intensywność linii analitycznych, przed każdą próbką regulowano intensywność piku $\mathrm{I}_{\mathrm{O}}$ względem wzorcowego preparatu kwarcowego.

Otrzymane $\mathrm{z}$ rentgenogramów wartości odległości międzypłaszczyznowych (w angstremach $\AA=0,1 \mathrm{~nm}$ ) wykorzystano do identyfikacji faz mineralnych wchodzących w skład badanych próbek. Do obróbki danych dyfrakcyjnych użyto programu komputerowego ClayLAB ver. 1.0. Identyfikację faz mineralnych oparto na bazie danych PCPDFWIN ver. 1.30 sformalizowanej przez JCPDS-ICDD.

Do obserwacji wykorzystano też skaningowy mikroskop elektronowy FEI Quanta 200 FEG, wyposażony w system do analizy w mikroobszarze EDS EDAX, jak również w detektor elektronów wstecznie rozproszonych (YAG BSE). Próbki przed obserwacjami napylono węglem.

Analizy chemiczne obejmowały oznaczenie: zawartości wilgoci analitycznej, strat prażenia, podstawowego składu chemicznego w przeliczeniu na tlenki, tj. $\mathrm{SiO}_{2}, \mathrm{Al}_{2} \mathrm{O}_{3}, \mathrm{Fe}_{2} \mathrm{O}_{3}$, $\mathrm{CaO}, \mathrm{MgO}, \mathrm{Na}_{2} \mathrm{O}, \mathrm{K}_{2} \mathrm{O}, \mathrm{SO}_{3}, \mathrm{TiO}_{2}, \mathrm{P}_{2} \mathrm{O}_{5}$, jak również $\mathrm{As}_{2} \mathrm{O}_{3}, \mathrm{PbO}_{2}, \mathrm{ZnO}$ i chloru oraz pierwiastków śladowych tj. Ag, As, $\mathrm{Ba}, \mathrm{Cd}, \mathrm{Co}, \mathrm{Cr}, \mathrm{Cu}, \mathrm{Mn}, \mathrm{Mo}, \mathrm{Ni}, \mathrm{Rb}, \mathrm{Sb}, \mathrm{Sn}, \mathrm{Sr}, \mathrm{V}$ oraz Tl. Oznaczenie zawartości wilgoci analitycznej i strat prażenia przeprowadzono metoda wagową. Podstawowy skład chemiczny oraz zawartość $\mathrm{As}_{2} \mathrm{O}_{3}, \mathrm{PbO}_{2}, \mathrm{ZnO}$ i pierwiastków śladowych, za wyjątkiem talu, oznaczone zostały metodą fluorescencyjnej spektrometrii rentgenowskiej z dyspersją fali WD XRF. Źródło wzbudzenia stanowiła lampa rentgenowska z podwójną anodą $\mathrm{Cr}-\mathrm{Au}$ o maksymalnej mocy $3 \mathrm{~kW}$. Natomiast Tl oznaczono metodą emisyjnej spektrometrii atomowej ze wzbudzeniem w plazmie indukcyjnej sprzężonej (ICP-OES), po wcześniejszym zmineralizowaniu próbki w wodzie królewskiej.

Charakterystyka powierzchni skał węglanowych została przeprowadzona za pomocą niskotemperaturowej izotermy adsorpcji azotu w temperaturze ciekłego azotu $-196,15^{\circ} \mathrm{C}$ stosując aparat firmy Micromeritics ASAP 2020.

Materiał badawczy przed analizą był odgazowywany pod niskim ciśnieniem w temperaturze $250^{\circ} \mathrm{C}$ przez 6 godzin. Po każdej analizie przeprowadzono pomiar wolnych przestrzeni za pomocą helu. Czas oznaczony jako okres równoważenia wynosił 30 sekund. Ciśnienie saturacji $\mathrm{p}_{0}$ było liczone $\mathrm{z}$ opcji temperaturowej zawartej $\mathrm{w}$ oprogramowaniu aparatu.

Powierzchnię właściwą BET oznaczono opierając się na teorii wielowarstwowej adsorpcji Braunauer'a-Emmett'a-Teller'a (Gregg, Sing 1982) przy p/p pomiędzy 0,06 i 0,3 (p ciśnienie równowagowe gazu w fazie objętościowej, $\mathrm{p}_{0}$ - ciśnienie pary nasyconej azotem). 
Objętość porów $\mathrm{V}_{\mathrm{p}}$ wyznaczono $\mathrm{z}$ objętości zaadsorbowanego azotu przy ciśnieniu $\mathrm{p} / \mathrm{p}_{0}=0,98$. Średnice porów $\mathrm{D}_{\mathrm{p}}$ obliczono według wzoru $\mathrm{Dp}=4 \mathrm{Vp} / \mathrm{S}_{\mathrm{BET}}\left(\right.$ gdzie $\mathrm{V}_{\mathrm{p}}$ objętość porów, $\mathrm{S}_{\mathrm{BET}}$ - powierzchnia właściwa BET).

Rozkład objętości porów $R_{p}$ wyliczono korzystając $\mathrm{z}$ ogólnego równania izotermy opartego na połączeniu zmodyfikowanego równania Kelvina i statystycznej grubości adsorbowanego filmu.

\section{Wyniki badań}

\subsection{Charakterystyka mineralogiczna}

Wytypowana do badań próbka odpadu poflotacyjnego została poddana podstawowym analizom mineralogicznym w celu scharakteryzowania obecności w niej dominujących faz mineralnych. Na podstawie analiz rentgenowskich (rys. 2) stwierdzono największy udział minerałów węglanowych, tj. dolomitu, ankerytu oraz kalcytu. Na krzywej dyfrakcyjnej również można zaobserwować piki pochodzące od gipsu (najprawdopodobniej powstałego w wyniku utleniania siarczków żelaza oraz neutralizacji kwasu siarkowego w reakcji z dolomitem), kwarcu oraz pirytu. Ponadto można zauważyć niezbyt duży udział galeny i sfa-

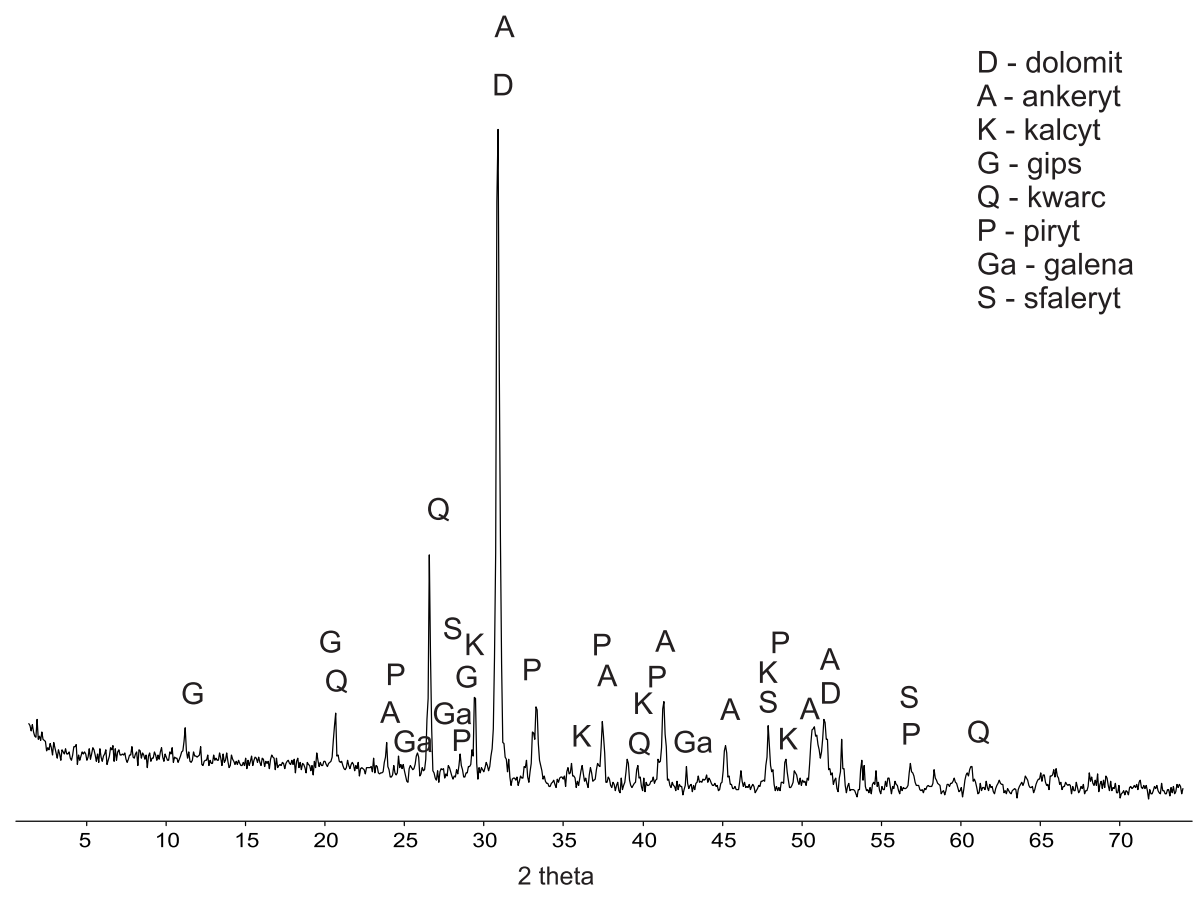

Rys. 2. Krzywa dyfrakcyjna XRD próbki odpadów poflotacyjnych z przemysłu Zn-Pb

Fig. 2. XRD diffraction pattern of flotation wastes sample from the $\mathrm{Zn}-\mathrm{Pb}$ industry 
lerytu, dające bardzo niewielkie piki na granicy szumów przy odległościach międzypłaszczyznowych dla galeny: $\mathrm{d}=2,97 \AA$ (zagłuszony przez intensywny pik pochodzący od ankerytu z dolomitem $\mathrm{d}=2,90 \AA$ ) $, \mathrm{d}=3,43 \AA$ i d $=2,09 \AA$ oraz dla sfalerytu $\mathrm{d}=3,12 \AA$, $1,91 \AA, 1,63 \AA(1 \AA=0,1 \mathrm{~nm})$. Obecność galeny i sfalerytu w odpadach poflotacyjnych potwierdzona została w obserwacjach SEM-EDS. Obserwacje mikroskopowe SEM-EDS (rys. 3) wykazały udział znacznie zróżnicowanych frakcji mineralnych o nierównomiernej wielkości ziaren. Wśród minerałów obserwuje się przede wszystkim udział minerałów węglanowych (głównie dolomitu), a także pojedyncze ziarna kwarcu i niewielkie ziarna galeny, rzadziej sfalerytu.

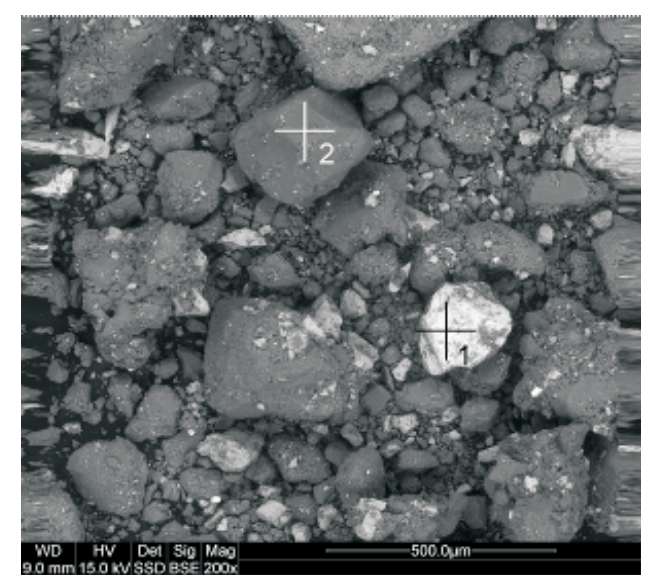

A) 1 - siarczek cynkowo-ołowiowy; 2 - kwarc

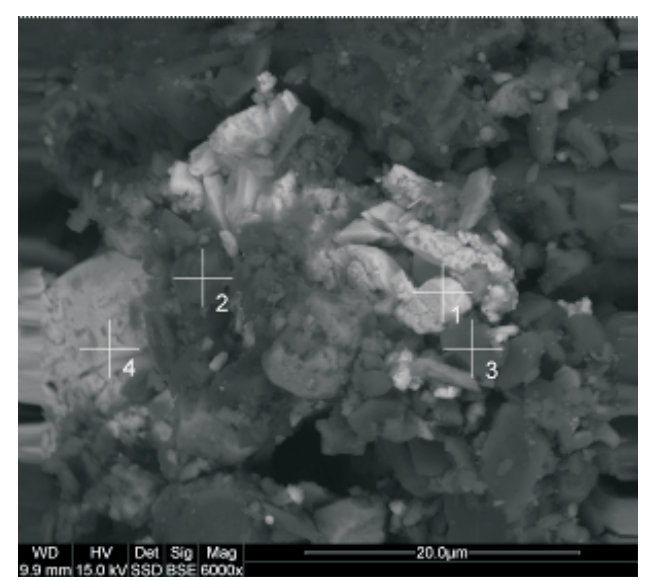

C) 1 - galena; 2 - węglan; 3 - dolomit; 4 - dolomit z galeną

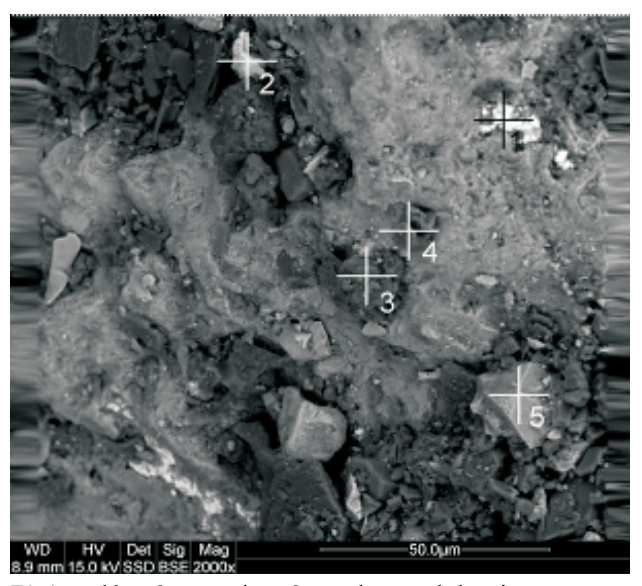

B) 1 - ołów, 2 - węglan; 3 - galena $\mathrm{z}$ dolomitem; 4 - dolomit

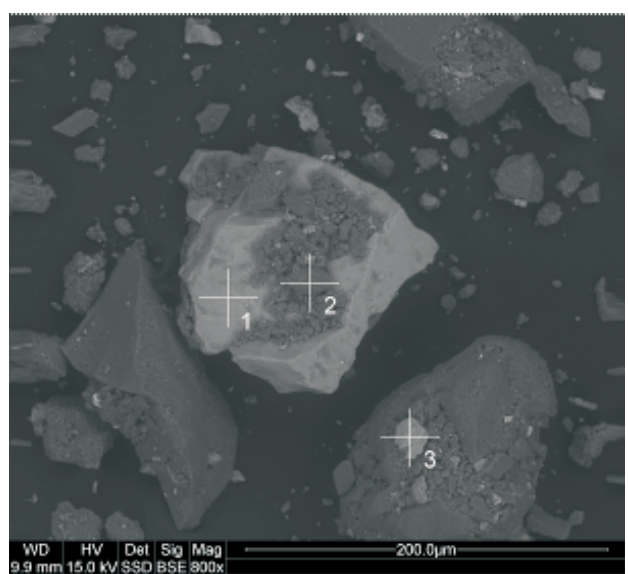

D) 1 - galena; 2 - kwarc; 3 - galena

Rys. 3. Mikrofotografie SEM odpadów poflotacyjnych z przemysłu Zn-Pb

Fig. 3. SEM microphotography of flotation wastes from the $\mathrm{Zn}-\mathrm{Pb}$ industry 
Wyniki uzyskane w badaniach mineralogicznych zbliżone są do rezultatów przedstawionych we wcześniejszych pracach (por. Kucha, Jędrzejczyk 1995; Cabała i in. 2008; Bauerek 2009). Różnice w obecności poszczególnych faz mineralnych wynikają z niejednorodności całego odpadu, różnic w czasie jakim były analizowane odpady poflotacyjne (technologia flotowania na przełomie lat ciagle ulega modyfikacji) oraz z uwagi na fakt, że próbki do badań przez poszczególnych autorów pobierane były w różnych miejscach składowiska. Zróżnicowanie mineralogiczne w badanym odpadzie związane jest z tworzeniem się $\mathrm{z}$ biegiem czasu minerałów wtórnych, dlatego w zależności od miejsca poboru odpadu, jak też długości czasu jego składowania, skład mineralny będzie odmienny. W starszym odpadzie obserwuje się większy udział minerałów wtórnych, takich jak np. gips, cerusyt, getyt, natomiast w młodszych odpadach przeważać będą minerały takie jak kalcyt, dolomit, piryt, sfaleryt, galena (Kucha, Jędrzejczyk 1995; Cabała i in. 2008).

\subsection{Charakterystyka chemiczna}

Analiza składu chemicznego (tab. 2) wykazała, że dominującymi składnikami badanego materiału są związki wapnia magnezu i żelaza ogólnego, co związane jest z przewagą

TABELA 2

Analiza składu chemicznego

Analysis of chemical composition

\begin{tabular}{|c|c|}
\hline Oznaczenie & $\begin{array}{c}\text { Zawartość po przeliczeniu na stan } \\
\text { wyjściowy [\% wag.] }\end{array}$ \\
\hline \hline $\mathrm{SiO}_{2}$ & 8,39 \\
\hline $\mathrm{Al}_{2} \mathrm{O}_{3}$ & 0,41 \\
\hline $\mathrm{Fe}_{2} \mathrm{O}_{3}$ & 11,59 \\
\hline $\mathrm{CaO}$ & 26,24 \\
\hline $\mathrm{MgO}$ & 10,99 \\
\hline $\mathrm{Na}_{2} \mathrm{O}$ & 0,01 \\
\hline $\mathrm{K}_{2} \mathrm{O}$ & 0,10 \\
\hline $\mathrm{SO}_{3}$ & 10,96 \\
\hline $\mathrm{TiO}_{2}$ & 0,01 \\
\hline $\mathrm{P}_{2} \mathrm{O}_{5}$ & 0,02 \\
\hline $\mathrm{As}_{2} \mathrm{O}_{3}$ & 0,12 \\
\hline $\mathrm{PbO}_{2}$ & 1,37 \\
\hline $\mathrm{ZnO}$ & 1,78 \\
\hline $\mathrm{Chlor}$ & 0,11 \\
\hline Straty prażenia & 27,36 \\
\hline $\mathrm{Suma}$ & 99,46 \\
\hline
\end{tabular}


minerałów węglanowych (dolomitu, kalcytu i ankerytu) w rudach, z których pozyskiwany jest cynk i ołów. Również obecność wapnia i żelaza w odpadzie związana jest $\mathrm{z}$ takimi minerałami jak: piryt i markasyt $\left(\mathrm{FeS}_{2}\right)$, getyt $(\mathrm{FeO}(\mathrm{OH}))$, gips $\left(\mathrm{CaSO}_{4} \cdot 2 \mathrm{H}_{2} \mathrm{O}\right)$ (Bauerek i in. 2009). Zawartość tych składników w przeliczeniu na tlenki wynosi średnio: $\mathrm{CaO} \sim 26 \%$ wag., $\mathrm{MgO} \sim 11 \%$ wag., $\mathrm{Fe}_{2} \mathrm{O}_{3} \sim 12 \%$ wag. Istotny udział w próbce przypada również na związki siarki, których zwartość w przeliczeniu na $\mathrm{SO}_{3}$ wynosi $\sim 11 \%$ wag., co wynika $\mathrm{z}$ obecności $\mathrm{w}$ analizowanym materiale minerałów siarczkowych oraz siarczanowych, powstałych w wyniku utleniania minerałów siarczkowych żelaza, w mniejszym stopniu siarczków cynku i ołowiu (Witczak, Postawa 1993; Cabała 1995). Zaobserwowano stosunkowo duży udział krzemionki ( $>$ \%), która powszechnie występuje w przyrodzie. Analizy chemiczne wykazały także podwyższone zawartości cynku ( $\mathrm{ZnO} \sim 2 \%$ ) i ołowiu ( $\mathrm{PbO} \sim 1 \%$ ), które stanowią pozostałość flotacji cynku i ołowiu. Obecność cynku związana jest $\mathrm{z}$ udziałem $\mathrm{w}$ odpadzie sfalerytu i smitsonitu, natomiast ołowiu - z galena i cerusytem (Górecka i in. 1994; Kucha, Jędrzejczyk 1995). Duży udział mają straty prażenia (LOI $\sim 27 \%$ ), natomiast wilgotność analityczna wyniosła 0,54\% wag.

TABELA 3

Zawartość pierwiastków śladowych w analizowanym materiale

Trace elements content in analyzed material

\begin{tabular}{|c|c|}
\hline Oznaczenie & $\begin{array}{l}\text { Zawartość poszczególnych pierwiastków } \\
\text { śladowych [ppm] }\end{array}$ \\
\hline $\mathrm{Ag}$ & $<2$ \\
\hline As & 862 \\
\hline $\mathrm{Ba}$ & 347 \\
\hline $\mathrm{Cd}$ & 84 \\
\hline $\mathrm{Co}$ & $<3$ \\
\hline $\mathrm{Cr}$ & 19 \\
\hline $\mathrm{Cu}$ & 62 \\
\hline $\mathrm{Mn}$ & 493 \\
\hline Mo & 4 \\
\hline $\mathrm{Ni}$ & $<2$ \\
\hline $\mathrm{Rb}$ & 12 \\
\hline $\mathrm{Sb}$ & 6 \\
\hline Sn & $<2$ \\
\hline $\mathrm{Sr}$ & 80 \\
\hline $\mathrm{V}$ & 7 \\
\hline $\mathrm{T} 1^{*}$ & 48 \\
\hline
\end{tabular}

* Oznaczony metodą ICP-OES 
Badania zawartości pierwiastków śladowych (tab. 3) wykazały największy udział arsenu tj. 862 ppm, który jest pierwiastkiem często występującym w minerałach siarczkowych, jak również manganu (493 ppm). Ponadto znaczące koncentracje zanotowano dla baru (347 ppm), który występuje często z minerałami siarczanowymi.

Porównując wyniki stężenia metali udostępnione przez ZGH „Bolesław” w 2009 roku $\mathrm{z}$ testu podstawowego wymywania wodnego składowanych odpadów poflotacyjnych (Raport z badań nr 7300/LB/2009) stwierdzono, że nie przekraczają one granicznych wartości wymywania, które decydują o możliwości skierowania odpadów innych niż niebezpieczne i obojętne (a do takich zaliczamy analizowane odpady poflotacyjne) do składowania na składowisku danego typu (załącznik nr 4 do Rozporządzenia Ministra Gospodarki i Pracy z dnia 7 września 2005 r. w sprawie kryteriów oraz procedur dopuszczania odpadów do składowania na składowisku odpadów danego typu - Dz.U. 2005, Nr 186, poz. 1553).

Wyniki te sugeruja, że wymywanie wodne nie stwarza zagrożenia środowiskowego, jednak wskazane byłoby przeprowadzenie dodatkowych badań w celu określenia stopnia wymywalności metali ciężkich z opadów w środowisku z gazem kwaśnym (tj. w środowisku kwasowym). Należy podkreślić, iż badania przeprowadzone przez Sikorę i in. (1996) wykazały, że odpady poflotacyjne charakteryzują się bardzo dużą pojemnością buforową.

\subsection{Charakterystyka teksturalna}

W analizie teksturalnej oznaczone zostały: powierzchnia właściwa BET, średnia średnica porów, średnia wielkość cząstek, średnia szerokość porów, objętość porów. Oznaczone parametry teksturalne przedstawiono w tabeli 4. Średnia wielkość cząstek jest stosunkowo duża i wynosi ponad 1,5 $\mu \mathrm{m}$, co jest prawdopodobnie związane z dużą ilością węglanów, które mają zbliżone wartości jeśli chodzi o wielkość cząsteczek. Rozważając średnią średnicę porów $(\sim 12 \mathrm{~nm})$ oraz średnią szerokość porów $(\sim 7 \mathrm{~nm})$ widać, że wartości znacznie różnią się od siebie, co wskazuje na podłużny kształt porów. Bardzo niska wartość objętości porów jest charakterystyczna dla mikroporowatych materiałów.

TABELA 4

Parametry teksturalne odpadu poflotacyjnego

TABLE 4

Textural parameters of flotation wastes

\begin{tabular}{||c|c|c|c|c|c||}
\hline \hline Próbka & $\begin{array}{c}\text { Średni rozmiar } \\
\text { cząsteczek } \\
{[\mathrm{nm}]}\end{array}$ & $\begin{array}{c}\text { Objętość } \\
\text { porów } \\
{\left[\mathrm{cm}^{3} / \mathrm{g}\right]}\end{array}$ & $\begin{array}{c}\text { Średnia średnica } \\
\text { porów BJH 4 V/A } \\
{[\mathrm{nm}]}\end{array}$ & $\begin{array}{c}\text { Powierzchnia } \\
\text { właściwa BET } \\
{\left[\mathrm{m}^{2} / \mathrm{g}\right]}\end{array}$ & $\begin{array}{c}\text { Średnia szerokość } \\
\text { porów 4 V/Å by } \\
\text { BET [nm] }\end{array}$ \\
\hline \hline $\begin{array}{l}\text { Odpad } \\
\text { poflotacyjny }\end{array}$ & 1565,6398 & 0,07 & 12,2689 & 3,8323 & 6,91538 \\
\hline \hline
\end{tabular}


Dla badanego materiału wykreślone zostały również izotermy adsorpcji/desorpcji azotu (rys. 4). Analizy izoterm dla skał węglanowych wskazują, że skały te charakteryzuje IV typ izoterm według klasyfikacji IUPAC (Międzynarodowa Unia Chemii Czystej i Stosowanej International Union of Pure and Applied Chemistry) potwierdzając mikroporowaty charakter skał, natomiast pętle histerezy zaliczyć można jako typ H3, sugerujący szczelinowaty kształt porów (Klinik 2000).

Rozkład wielkości porów dla skał węglanowych określony został w zakresie 1,7-300 nm (rys. 5). Zmienność w wielkości porów obserwuje się w zakresie od 2-30 nm z przewagą

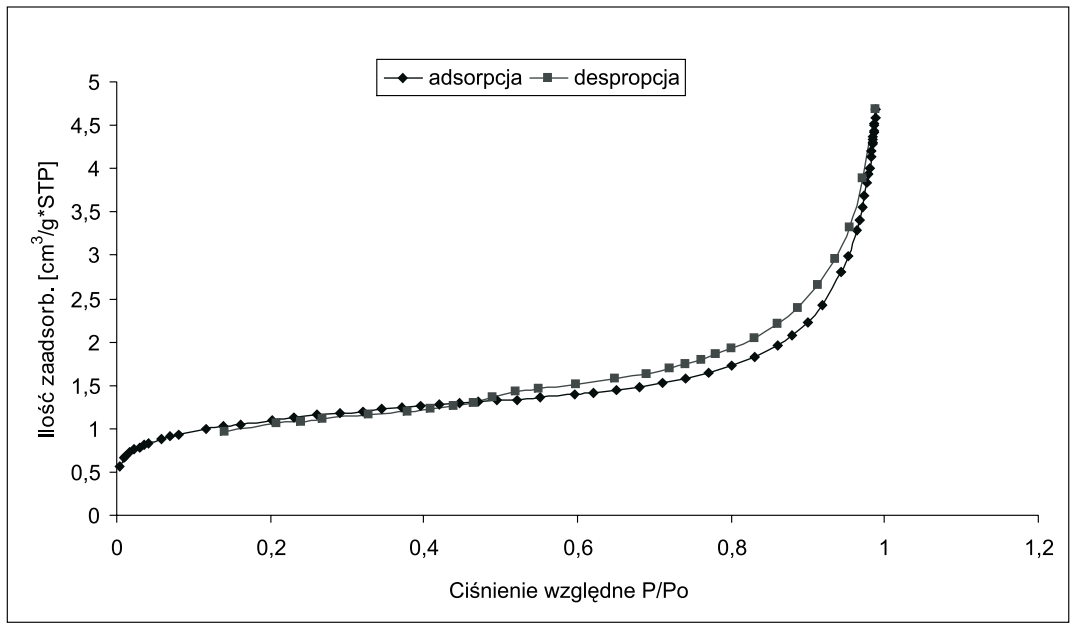

Rys. 4. Izoterma adsorpcji/desorpcji $\mathrm{N}_{2}$ odpadu poflotacyjnego

Fig. 4. $\mathrm{N}_{2}$ sorption/desorption isotherms of flotation wastes

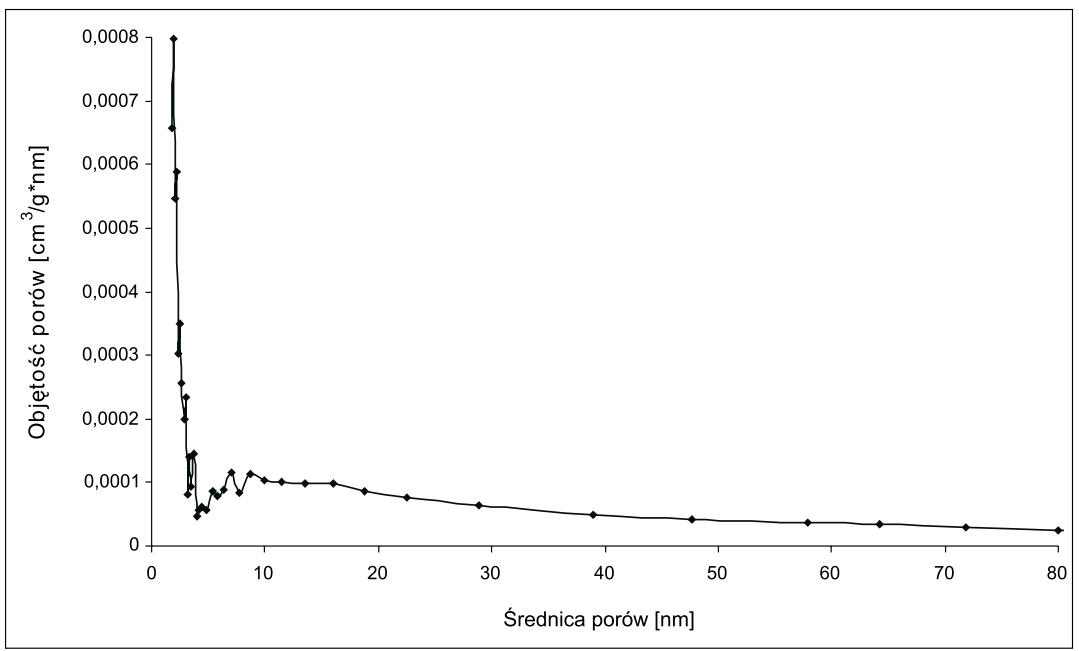

Rys. 5. Rozkłady objętości porów według średnic obliczone metodą BJH z danych adsorpcji azotu

Fig. 5. Distribution of pore volumes by diameters calculated by BJH method from nitrogen adsorption data 
porów o średnicy $2 \mathrm{~nm}$. Widoczne są również niewielkie maksima w zakresie 8-10 nm oraz przy średnicy porów $5 \mathrm{~nm}$. Rozkład porów jest heterogeniczny.

\section{Podsumowanie i wnioski}

Odpady poflotacyjne z uwagi na fakt, że zawierają w sobie metale ciężkie niechętnie i z ostrożnością są rozpatrywane jako materiał do wtórnego wykorzystania. Głównie wykorzystywane są w górnictwie jako składnik podsadzki hydraulicznej, ale też przy rekultywacji terenów pogórniczych, tj. wypełniania zapadlisk i odkrywek (Girczys, Sobik-Szołtysek 2002; Jarosiński i in. 2005; Kulczycka i in. 2005; Pajor 2005; Włodarczyk i in. 2005; Butra $\mathrm{i}$ in. 2007).

Materiał nadający się do wykorzystania jako sorbenty powinien charakteryzować się dobrymi właściwościami sorpcyjnymi, które zapewnia wysoka powierzchnia właściwa oraz duża pojemność jonowymienna. Za te parametry odpowiedzialny jest skład mineralny, chemiczny jak również tekstura analizowanego materiału. Dlatego, aby rozpocząć tego typu rozważania, konieczne jest przeprowadzenie podstawowych badań mineralogicznych, chemicznych i teksturalnych.

Jak już wcześniej wspomniano celem artykułu była jedynie wstępna charakterystyka mineralogiczna, chemiczna i teksturalna pod kątem podjęcia dalszych badań oraz weryfikacji możliwości wykorzystania materiału poflotacyjnego jako sorbentu gazów kwaśnych (tj. $\mathrm{SO}_{2}$ i $\mathrm{CO}_{2}$ ).

Badania mineralogiczne (podobnie jak w przypadku analiz prowadzonych przez np. Górecką i in. 1994; Kuchę, Jędrzejczyka 1995 czy Bauerka i in. 2009) wykazały, że dominującymi składnikami mineralnymi obserwowanymi na krzywej dyfrakcyjnej oraz w analizach SEM są węglany (kalcyt, dolomit, ankeryt), w niewielkich ilościach zaobserwowano gips, kwarc, piryt, galenę i sfaleryt. Taki skład mineralny może wskazywać na słabe właściwości adsorpcyjne odpadów poflotacyjnych (brak w składzie mineralnym minerałów o dobrych właściwościach adsorpcyjnych tj. minerałów ilastych i zeolitów). Niemniej jednak węglany wykorzystywane są w metodach odsiarczania gazów wylotowych (Pisani, Mores 2003), głównie sorbentów w mokrych instalacjach odsiarczania spalin (Chmielarz i in. 2002) lub w metodach karbonizacji $\mathrm{CO}_{2}$ (Fang i in. 2009), dlatego też można podjąć próbę przeprowadzenia prostych eksperymentów laboratoryjnych unieszkodliwiania tych gazów przy wykorzystaniu odpadów poflotacyjnych.

$\mathrm{Na}$ niekorzystne właściwości sorpcyjne wskazują również wyniki uzyskane w analizach teksturalnych, gdzie odpady te charakteryzują się niską powierzchnią właściwą BET (zaledwie $3,8 \mathrm{~m}^{2} / \mathrm{g}$; w przypadku minerałów o dobrych właściwościach adsorpcyjnych powierzchnia właściwa BET jest znacznie większa - nawet 100× i więcej - (Klinik 2000)) oraz stosunkowo dużym rozmiarem ziaren $(1565,63 \mathrm{~nm})$. Niemniej jednak analizowane materiały posiadają stosunkowo duże rozmiary porów (średni rozmiar i szerokość porów rzędu 7-12 nm), co może korzystnie wpływać na sorpcję gazów kwaśnych. Przewaga porów 
obserwowana w zakresie $2 \mathrm{~nm}$ sugeruje mikroporowaty charakter analizowanego materiału. Natomiast heterogeniczny rozkład porów (jak można zaobserwować na rys. 5) sugeruje, że większość szerszych porów może występować przykładowo na powierzchni ziaren sorbentu lub pomiędzy mikroziarnami, podczas gdy większe pory mogą znajdować się wewnątrz ziaren, będąc przedłużeniem szerszych porów. Dlatego też wskazane byłoby dodatkowo oznaczyć pojemność jonowymienną w odpadach.

W wykorzystaniu odpadów poflotacyjnych jako sorbentów gazów kwaśnych wątpliwości może budzić zawartość w nich metali ciężkich obserwowanych w analizie chemicznej (głównie Zn i Pb, których ilość w przeliczeniu na tlenki wynosi odpowiednio 1,78\% wag. i 1,34\% wag. oraz w mniejszych ilościach As 862 ppm, Mn 439 ppm i Ba 347 ppm), które mogą uwalniać się do środowiska. Jednak badania wymywalności przeprowadzone przez Sikorę i in. (1996) zarówno w środowisku wodnym jak i kwaśnym wykazały, że odpady poflotacyjne charakteryzują się dużą pojemnością buforową. Aczkolwiek, w celu immobilizacji metali ciężkich w planowanych eksperymentach, bezpieczniej byłoby spróbować wykorzystać domieszki materiałów immobilizujących metale ciężkie w odpadach poflotacyjnych, np. wapno, zeolity (naturalne lub syntetyczne), minerały ilaste, tlenki Fe-Mn, apatyt, kompost, popioły lotne, dodatki pucolanowe (Gworek 1993; LaGrega i in. 1994; Helios-Rybicka, Wójcik 2005).

Na uwagę zasługuje również fakt, iż badania sekwencyjnej ekstrakcji chemicznej przeprowadzone przez Helios-Rybicką i Sikorę w 1996 wykazały, że największa ilość metali związana jest w residuum i z węglanami odpowiednio $42 \%$ i $21 \%$ Zn, 36 \% i $37 \%$ Pb oraz $25 \%$ i $40 \%$ Cd. Natomiast zaledwie 17\% metali występuje w formach jonowymiennych, niebezpiecznych dla środowiska. Dodatkowo przy przechodzeniu związków siarczkowych w wyniku utleniania w związki siarczanowe (co będzie miało miejsce zarówno na składowisku, jak też podczas metod odsiarczania) metale ciężkie wiązane są w nich w sposób trwały, trudny do uwolnienia (Cabała 2005).

Należy podkreślić, że w przypadku planowanych dalszych badań wykorzystania odpadów poflotacyjnych do neutralizacji gazów kwaśnych, będą one stanowić jedynie doświadczenia eksperymentalne, bez pewności uzyskania pozytywnych wyników dla praktycznego ich wykorzystania.

Istotne jest, że dla tego typu odpadów do dnia dzisiejszego nie znaleziono innego przemysłowego wykorzystania niż wbudowywanie w strukturę składowiska lub wypełnianie pustek poeksploatacyjnych. Zagospodarowuje to odpady z bieżącej produkcji, natomiast znaczna ilość odpadów znajduje się na składowisku, które pozostaje stałym elementem krajobrazu. Brak realnych możliwości na całkowite i szybkie zagospodarowanie odpadów powstających przy produkcji koncentratów $\mathrm{Zn}$ i Pb uniemożliwia na dzień dzisiejszy docelową likwidację stawów osadowych (Pajor 2005). Z tego powodu eksperymentalne próby ich praktycznego wykorzystania wydają się być uzasadnione. 


\section{LITERATURA}

Alw a e li M., C ze c h Ł., 2009-Możliwości gospodarczego wykorzystania odpadów poflotacyjnych. Archiwum Gospodarki Odpadami i Ochrony Środowiska. Vol. 11, Issue 3, s. 47-62.

Bauerek i in. 2009 - B a uerek A., Ca bała J., S miej a-Kró1 B., 2009 - Mineralogical Alterations of Zn-Pb Flotation Wastes of Mississipi Valley-Type Ores (Suothern Poland) and Their Impact on Contamination of Rainwater Runoff, Polish Journal of Environmental Studies, vol. 18, nr 5, s. 781-788.

Butra i in. 2007 - B u tr a J., D ę b k ow sk i R., Mi zer a A., 2007 - Zagospodarowanie odpadów poflotacyjnych. Rudy i Metale, R 42, nr 8, s. 322-328.

Ca b ała J., 2005 - Kwaśny drenaż odpadów poflotacyjnych rud Zn-Pb; Zmiany składu mineralnego w strefach ryzosferowych rozwiniętych na składowiskach. Zeszyty Naukowe Politechniki Śląskiej 1690, s. Górnictwo z. 267 , s. $63-70$

Chmielarz i in. 2002 - Chmielarz A., Mrozowski J., Wasilewski W., Jaschik M., 2002 - Dolomitowe odpady flotacyjne jako sorbenty w procesie mokrego odsiarczania gazów. Rudy i Metale, nr 7, s. 324-328.

Duda R., Witczak S., 2003 - Modeling of the transport of contaminants from the Żelazny Most flotation tailings dam, Gospodarka Surowcami Mineralnymi t. 19, z. 4. s. 69-88.

Fang i in. $2009-\mathrm{F}$ ang F., Li Z.S., C a i N.S., $2009-\mathrm{CO}_{2}$ capture from flue gases using a fluidized bed reactor with limestone. Korean Journal of Chemical Engineering, 26 (5), s. 1414-1421.

Girczys J.K., S obik-Szołtysek J., 1997 - Problemy wykorzystania osadników poflotacyjnych rud Zn-Pb rejonu bytomskiego. Rudy i Metale, R. 42, nr 7, s. 297-302.

Girczys J.K., Sobik-Szołtysek J., 2002 - Odpady przemysłu cynkowo-ołowiowego. Seria Monografie nr 87. Wydawnictwo Politechniki Częstochowskiej, Częstochowa.

Górecka i in. 1994-Gór e ck a E., B ellok A., S o ch a J., W nuk R., Kibitlew ski S., 1994-Zróżnicowanie zawartości metali w odpadach flotacyjnych rud Zn-Pb (ZGH Bolesław, rej. Olkuski). Przegląd Geologiczny, vol. 42 , nr 10, s. 834-841.

Gre g g S. J., S in g K.S.W., 1982 - Adsorption, Surface Area and Porosity. $2^{\text {nd }}$ edition. Academic Press. London.

Guśpiel i in. 1997 - Guśpiel J., Gierat K., Kazibut J., Polonka Z., 1997 - Kompleksowa metoda utylizacji odpadów cynkonośnych. Rudy i Metale, R 42, nr 1, s. 3-9.

Gworek B., 1993 - Wpływ zeolitów na zmniejszenie akumulacji metali ciężkich w roślinach uprawianych na glebach zanieczyszczonych. Wydawnictwo SGGW, Warszawa.

Heli o s-R y bicka E., Sikora W., 1996 - Charakterystyka chemiczna i fazowa odpadów z ZGH „Bolesław” w Bukownie oraz mobilność cynku, ołowiu i kadmu. Praca niepublikowana - archiwum Zakładu Ochrony Środowiska AGH, WGGiOŚ, Kraków.

Helios-Rybicka E., Wójcik R., 2005 - Heavy metals ( $\mathrm{Zn}, \mathrm{Pb}, \mathrm{Cd}, \mathrm{Tl})$ and $\mathrm{As}$ - their mobilization and immobilization in the wastes from the $\mathrm{Zn}-\mathrm{Pb}$ mining and smelting industry at the Bukowno, Upper Silesia, Poland. June 27-July 1, 2005, Skallefteå, Sveden: proceedings, Vol. 1/MITU [etc.]. s. 389-398.

Janiec R., Nowak J., 1973 - Odpady z przeróbki rud Zn-Pb i ich mieszaniny z piaskiem jako materiał podsadzkowy. Rudy i metale nieżelazne, R. 13, nr 9, s. 428-432.

Jarosiński i in. 2005 - Jaros ińsk i A., Że lazn y S., Włodarczyk B., 2005 - Badanie możliwości zagospodarowania odpadu z procesu wzbogacania rud cynkowo-ołowiowych do wypełniania pustek górniczych. [W]: Kudełko J., Kulczycka J., Wirth H., 2005 - Zrównoważone zarządzanie obszarami poprzemysłowymi. Wydawnictwo IGSMiE PAN, Kraków, s. 66-72.

Katalog - Odpady w przemyśle metali nieżelaznych, 2002.

Klinik J., 2000 - Tekstura porowatych ciał stałych/Texture of porosity solids. AGH - Ośrodek Edukacji Niestacjonarnej, Kraków.

K u cha H., Jędrzejczyk B., 1995 - Primary minerals of mining and metalurgical $\mathrm{Zn}-\mathrm{Pb}$ dumps at Bukowno, and their stability during wathering. Mineralogica Polonica, 26 (2), s. 75-99.

Kulczycka i in. 2005 - Kulczycka J., Plewa F., Włodarczyk B., 2005 - Możliwość wykorzystania odpadów powstających przy wzbogacaniu rud cynkowo-ołowiowych z ZG „Trzebionka” S.A. [W]: Kudełko J., Kulczycka J., Wirth H., 2005 - Zrównoważone zarządzanie obszarami poprzemysłowymi. Wyd. IGSMiE PAN, Kraków, s. 163-172. 
LaGrega i in. 1994 - La Gre g a M.D., B u c king h a m P.L., Ev a n s J.C., 1994 - Hazardous waste management McGraw-Hill, Inc. s. 1146.

P a j o r G., 2005 - Gospodarka odpadami poflotacyjnymi w ZGH Bolesław S.A. w Bukownie. [W]: Kudełko J., Kulczycka J., Wirth H., 2005 - Zrównoważone zarządzanie obszarami poprzemysłowymi. Wyd. IGSMiE PAN, Kraków, s. 8-19.

P is a n i R., Mores D., 2003 - Removal of $\mathrm{SO}_{2}$ with particles of dolomite limestone powder in a binary fluidized bed reactor with bubbling fluidization. Brazilian Journal of Chemical Engineering vol. 20, no 2.

Raport z badań nr 7300/LB/2009 Laboratorium Ośrodka Badań i Kontroli Środowiska Sp. z o.o. (udostępnione przez ZGH "Bolesław").

Rozporządzenie Ministra Gospodarki i Pracy z dnia 7 września 2005 r. w sprawie kryteriów oraz procedur dopuszczania odpadów do składowania na składowisku odpadów danego typu (Dz.U. 2005, Nr 186, poz. 1553).

Sikora i in. 1996 - Sikora W., Damian E., Jędrzejczyk B., Szczawiński W., Wardas M., 1996 Charakterystyka odpadów z ZGH „Bolesław” w Bukownie. Ochrona Powietrza z. 4, s. 143-146.

Sztaba i in. 1996 - Sztaba K., Kuczyńska I., S anak-Rydlewska S., Ociepa Z., 1996 - Utylizacja odpadów cynkowo-ołowiowych. Rudy i Metale, R. 41, nr 3, s. 154-158.

Szuwarzyński M., Kryza A., 1993 - Problem odpadów flotacyjnych w górnictwie rud cynku i ołowiu na obszarze śląsko-krakowskiej prowincji złożowej. Przegląd Geologiczny, vol. 41, nr 9, s. 629-633.

Śmieszek Z., Sobierajski S., 1998 - Kierunki rozwoju przemysłu metali nieżelaznych. Rudy i metale, R. 43, nr 1, s. 9-16.

Witczak S., Postawa A., 1993 - Ocena szybkości ługowania siarczków z płonych skał karbońskich deponowanych na składowiskach Górnośląskiego Zagłębia Węglowego, na podstawie badań lizymetrycznych. Prace Mineralogiczne, Komisja Nauk Mineralogicznych PAN w Krakowie, s. 61-64.

Włodarczyk B., Mazanek C., Kulczycka J., 2005 - Propozycja opracowania technologii wykorzystania odpadów poflotacyjnych do podsadzania. [W]: Kudełko J., Kulczycka J., Wirth H., 2005: Zrównoważone zarządzanie obszarami poprzemysłowymi. Wyd. IGSMiE PAN, Kraków, s. 153-162.

CHARAKTERYSTYKA MINERALOGICZNO-CHEMICZNA I TEKSTURALNA ODPADÓW POFLOTACYJNYCH Z PRZEMYSLU ZN-PB POD KĄTEM DALSZYCH ROZWAŻAŃ WYKORZYSTANIA ICH JAKO SORBENTÓW

Słowa kluczowe

Odpady poflotacyjne, rudy $\mathrm{Zn}-\mathrm{Pb}$, badania mineralogiczno-chemiczne, analizy teksturalne

\section{Streszczenie}

Celem pracy była wstępna charakterystyka (mineralogiczna, chemiczna, teksturalna) odpadów poflotacyjnych, stanowiących surowiec uboczny (odpadowy) przy uzyskiwaniu koncentratów cynkowo-ołowiowych, pod kątem dalszych analiz nad możliwością ich perspektywicznego (eksperymentalnego) wykorzystania jako sorbentów gazów kwaśnych $\left(\mathrm{SO}_{2}\right.$ i $\left.\mathrm{CO}_{2}\right)$. Składowisko tych odpadów jest własnością ZGH „Bolesław” w Bukownie. Materiał badawczy stanowiła próbka odpadów poflotacyjnych pobrana ze stawu osadowego $\mathrm{nr} 1$, leżącego w południowej części Stawu Zachodniego. Charakterystyka wytypowanych do badań materiałów obejmowała podstawowe badania mineralogiczne (XRD, SEM-EDS), analizy chemiczne (oznaczenie zawartości wilgoci analitycznej, zawartości strat prażenia, podstawowego składu chemicznego, jak też pierwiastków śladowych) oraz wyznaczenie podstawowych parametrów teksturalnych (powierzchnia właściwa BET, rozkład i wielkość porów). Badania mineralogiczne wykazały, że materiał odpadowy stanowią głównie minerały węglanowe (w przewadze kalcyt, dolomit, ankeryt) oraz minerały stanowiące pozostałość po niewyflotowanych kruszcach (w przewadze galena, sfaleryt). Analiza chemiczna pozwoliła stwierdzić, iż w analizowanej próbce dominują związki wapnia, magnezu i żelaza uwarunkowane przewagą minerałów węglanowych w badanych odpadach. Wśród pierwiastków śladowych przeważa arsen, następnie mangan i bar, występujące jednak w ilości 
nie przekraczającej $1 \%$. Analiza teksturalna wykazała, że materiał badawczy charakteryzuje się niską powierzchnią właściwą i dużymi rozmiarami cząstek. Przeprowadzone badania sugerują, że analizowany materiał charakteryzuje się ubogimi właściwościami adsorpcyjnymi, aczkolwiek mógłby on znaleźć zastosowanie w metodach odsiarczania, jak też neutralizacji dwutlenku węgla (karbonizacja). Należałoby jednak w tym celu przeprowadzić dodatkowe badania wymywalności metali ciężkich w środowisku kwasowym, jak też zastosować domieszki innych składników, takich jak cement czy zeolity, w celu immobilizacji niebezpiecznych składników odpadów.

MINERALOGICAL-CHEMICAL AND TEXSTURAL CHARACTERISTICS OF ZN-PB INDUSTRY FLOTATION WASTES WITH FURTHER POTENTIAL FOR APPLICATION AS SORBENTS

$$
\text { Key words }
$$

Flotation wastes, $\mathrm{Zn}-\mathrm{Pb}$ ores, mineralogical-chemical research, textural analysis

\section{Abstract}

The aim of this study was a preliminary characterization (mineralogical, chemical, textural) of flotation wastes - which are the by-product of zinc-lead concentrate extraction - from the standpoint of their further prospective (experimental) use as sorbents of acid gases $\left(\mathrm{SO}_{2}\right.$ and $\left.\mathrm{CO}_{2}\right)$. The landfill sourced for the wastes used in this study was owned by ZGH "Bolesław" in Bukowno. The research material consisted of a sample of flotation wastes taken from alluvial pond No. 1, lying in the southern part of the Western Pond. Characterization of the material selected for testing included the following: basic mineralogical (XRD, SEM-EDS) and chemical analysis (determination of analytical moisture content, loss on ignition, basic chemical composition, and content of trace elements), as well as the identification of basic textural parameters (BET specific surface area and pore size distribution). Mineralogical studies showed that the waste material consisted mainly of carbonate minerals (primarily calcite, dolomite, ankerite) and minerals present in the residuum after ore flotation (primarily galena and sphalerite). The chemical analysis indicated that in analyzed samples, calcium, magnesium, and iron components are predominant. They are conditioned by carbonate minerals which predominate in the studied waste. The most significant trace elements were arsenic, followed by manganese, and then bar - present only in quantities not exceeding 1\%. Textural analysis showed that the test material has a low surface area and large particle size. The research suggests that the analyzed materials have poor adsorption properties, although they could be used in desulfurization as well as the neutralization of carbon dioxide (carbonation). However, it is necessary for this purpose to conduct additional studies of heavy metals' leaching in an acidic environment, in addition to applying the admixture of other ingredients to the flotation wastes, such as cement or zeolites, to immobilize hazardous waste components. 
